\title{
Phytochemistry of the Genus Equisetum (Equisetum arvense)
}

\author{
Raghda Makia ${ }^{1,}{ }^{*}$, Khulood W Al.sammarrae ${ }^{2}$, Mohammad MF Al-Halbosiy ${ }^{3}$ and Mohammed H Al-Mashhadani 4 \\ ${ }^{1}$ Biotechnology College, Al-Nahrain University, Baghadad, Iraq. \\ 2 Department of Forensic Techniques, Al-Farahidi University, Baghadad, Iraq. \\ ${ }^{3}$ Biotechnology Research Center, Al-Nahrain University, Baghadad, Iraq. \\ ${ }^{4}$ Department of Chemistry, College of Science, Al-Nahrain University, Baghdad, Iraq.
}

GSC Biological and Pharmaceutical Sciences, 2022, 18(02), 283-289

Publication history: Received on 01 January 2022; revised on 08 February 2022; accepted on 10 February 2022

Article DOI: https://doi.org/10.30574/gscbps.2022.18.2.0059

\begin{abstract}
The previous studies revealed that Equisetum arvense contained alkaloids, carbohydrate, proteins and amino acids, phytosterols, saponins, sterols, ascorbic acid, silicic acid, phenol, tannin, flavonoids, triterpenoids, volatile oils and many other biological active constituents. E. arvense has been used as a folklore medicine for treatment of various conditions such as tuberculosis, as a catarrh in the kidney and bladder regions, as a hematostatic for profuse menstruation, nasal, pulmonary, gastric hemorrhages and many other uses. The current review highlights the uses and phytochemical constituents of $E$. arvense.
\end{abstract}

Keywords: Equisetum arvense; Alkaloids; Phytosterols; Hematostatic; Flavonoids

\section{Introduction}

Plants that possess therapeutic properties or exert beneficial pharmacological effects on the human body are generally designated as medicinal plants. Medicinal plants naturally synthesize and accumulate some secondary metabolites like alkaloids, sterols, terpenes, flavonoids, saponins and glycosides. The medicinal plants have been used for the treatment of diseases and illness since the ancient times [1].

Iraq, like any other country of Middle East and elsewhere in the world, is differentiated into two societies: rural and urban; both of these societies depend largely on the rich traditional heritage of the use of medicinal plants for the treatment of different illnesses, hence folk medicine is widely practiced by the people of the cities and the inhabitants of the remote areas or the nomads who generally inhabit the desert areas of the steppe and the uplands [2-3].

\section{Family Equisetaceae}

Equisetaceae, also sometimes named as horsetail family, is the only extinct family of the order Equisetales, with one surviving genus, Equisetum, which comprises about twenty species. All available horsetails nowadays are belonging to Eqisetum genus Equisetum. Also, some fossils are found that did not classify in the new classification system. Equisetites is a "catch all taxon" unifying all different types of larger horsetails that belong to the Mesozic era [4].

\section{Genus Equisetum}

All Equisetum species are herbaceous perennials. The plants consist of upright aerial stems which arise from a very extensive underground rhizome system [5]. Morphologically, the genus Equisetum is characterized by jointed aerial

\footnotetext{
* Corresponding author: Raghda Makia

Biotechnology College, Al-Nahrain University Baghadad, Iraq.
}

Copyright (@) 2022 Author(s) retain the copyright of this article. This article is published under the terms of the Creative Commons Attribution Liscense 4.0. 
stems and jointed rhizomes. The stems of horsetails are anatomically unique among plants" [6] although they have an external appearance somewhat reminiscent of bamboo. The upright aerial stems exhibit a monopodial branching pattern, having one main axis of growth. Equisetum species also have small microphyllous leaves that are arranged in true whorls [7] and the leaves of each whorl are fused together to form a cylindrical sheath around each node [8]. Some but not all, species form whorls of lateral branches at the nodes of the aerial stems [9].

\section{Equisetum arvense}

Equisetum arvense commonly known as Horsetail is a bushy perennial herb, originally native to northern hemisphere E. arvense belongs to Equisetaceae family in the order of Equisetales that contains just only one living genus [10]. The genus Equisetum is divided into two subgenera Equisetum and Hippochaete based on some primary differences concerning macromorphology and micromorphology, gametophyte morphology, chromosome size, and nuclear DNA Cvalues [11]. Horsetail is a strange-looking sort of plant with creeping, string like rootstock and roots at the nodes that produce numerous hollow stems. Two markedly different types; the sterile stems tend to be much taller and bushier, with the jointed segments being around one inch long with a diameter of about $1 / 20$ th of an inch. These segments contain one set of whorled, slender, erect branches each. Some stems can have as many as 20 segments and be as tall as 2 to 24 inches. The fertile stems tend to be half as tall as the sterile stems and also tend to be more succulent. Fertile stems unbranched, appear in early spring, usually thick and succulent, brownish to whitish, 10 to $30 \mathrm{~cm}$ tall. Sterile stems bottlebrush-like (many whorls of slender branches), appear as fertile stalks wither 1-several in clusters, 10 to 50 $\mathrm{cm}$ tall; slender, green, 10 to 12 ridged, minutely roughened; branches simple, first branch segment longer than adjacent stem sheath [10].

\subsection{Distribution}

Equisetum arvense was distributed throughout Europe and Asia, south to Turkey, Iran, Iraq the Himalayas, and across China, Korea and Japan. It is also found throughout Canada and the USA [12-13].

Distribution of Equisetum arvense according to [14] is presented only in niberhood or the Ruwandiz district in the forest zone of Iraq Khalan and between Khoran and Haji-Umran and close to Rubari Rusta. Its habitat according to [Townsend 1966] is ditches in orchard moist silt of perennial streams at flood level by road side on mountain slop at altitude 1100$1500 \mathrm{~m}$ during June-September. [14] suggested that very restricted distribution of this species iv Iraq may be due to its restrictive to non-calcareous soil, lime free soil been very rear in our country but occurring in several localities to the north east of Ruwandiz. Equisetum arvenus have a very wide range of distribution in Kurdistan. It has been recorded from Gondazhour in Erbil district North West of Choman and also recorded far south of Kurdistan in Garmian area specifically in Qula Sotaw [15].

\subsection{Traditional uses}

For a long time, E. arvense has been used as a folklore medicine for treatment of various conditions such as tuberculosis, as a catarrh in the kidney and bladder regions, as a hematostatic for profuse menstruation, nasal, pulmonary and gastric hemorrhages, for brittle fingernails and loss of hair, for rheumatic diseases, gout, poorly healing wounds and ulcers, swelling and fractures and for frostbite. Horsetail can produce toxic effects on its prolonged use, especially when used for long. Alkaloids although do not appear in strong concentrations, a prolonged use, can take place by accumulating them in the organism which may facilitate premature childbirth, nervous disorders, headaches, loss of appetite, swallowing problems, etc. These intoxications force to a treatment that restores the thiamine deficiency, although in the case of the animals, they are no longer recoverable in many occasions [10].

\subsection{Chemical constituents}

The preliminary phytochemical analysis showed that the plant contained alkaloids, carbohydrate, proteins and amino acids, phytosterols, saponins, sterols, ascorbic acid, silicic acid, phenol, flavonoids and triterpenoids [10-16-17-18]. The plant contained silicic acid, tartaric acid, methyl esters of protocatechuic, caffeic acids isoquercitrin, apigenin and kaempferol as phenolic compounds [17-19-20-21]. Stem contained silicic acid and silicates (5-8\%), calcium (1.3\%), potassium (1.8\%) and other minerals such as aluminium, sulphur, phosphorus, sodium, zinc, magnesium and manganese [10-22-23-24]. Alkaloids such as nicotine, palustrine and palustrinine were isolated from the plant [25]. The total phenolic content of n-butanol, ethyl acetate and water extracts were 96.4, 26.4 and $15.4 \mathrm{mg} / \mathrm{g}$ of dry extracts, respectively [26]. The plant contained 0.6 to $0.9 \%$ flavonoids including apigenin glucoside, genkwanin glucoside, kaempferol glucoside, kaempferol sophoroside, luteolin glucoside, quercetin glucoside. It was also contained caffeic acid ester (up to $1 \%$ including chlorogenic acid, dicoffeoyl-meso-tartaric acid), 5-7.7\% silicic acid and pyridine alkaloids, and styrolpyrone glucosides [27-28-10-29]. The volatile constituents of the sterile stems of Equisetum arvense were 
investigated using GC, GC/MS and 13C-NMR. Twenty-five compounds were identified. Hexahydrofarnesyl acetone (18.34\%), cis-geranyl acetone (13.74\%), thymol (12.09\%) and trans-phytol (10.06\%) were the major constituents [30].

\subsection{Phytochemical active compounds of Equisetum arvense}

Horsetail (Equisetum arvense L.) is well known as culinary and medicinal herb. Its fertile stems are consumed as food in sweetened vinegar and in cooked food [31]. Horsetail was described as anti-inflammatory and antioxidant agent, vasorelaxant, and was highly recommended by herbalists as haemostatic [32-33]. These activities of horsetail are related to the content of several classes of secondary metabolites such as phenolics (flavonoids, styryl pyrones and phenolic acids), alkaloids (equisetin, nicotine, palustrine and palustrinine), phytosterols (campesterol), bitter principle and minerals (silica, calcium, magnesium, selenium, iron, potassium, zinc, etc.) [34-35-36-37]. The most widely known phytochemical compounds of Equisetum arvense L. are flavonoids, phenolic acids, alkaloids, phytosterols, tannins and triterpenoids [25].

\section{Phytochemical constituents of Equisetum arvense}

\subsection{Flavonoids and their Glycosides}

Flavonoids are an important class of natural products; particularly, they belong to a class of plant secondary metabolites having a polyphenolic structure, widely found in fruits, vegetables and certain beverages. Flavonoids, a term usually used to refer to a wide range of naturally occurring compounds that have (C6-C3-C6) base unit, or what is called phenyl benzopyran structure [38]. Flavonoids can be subdivided into different subgroups depending on the carbon of the $\mathrm{C}$ ring on which the $\mathrm{B}$ ring is attached and the degree of unsaturation and oxidation of the $\mathrm{C}$ ring (Figure 1). Flavonoids in which the $\mathrm{B}$ ring is linked in position 3 of the $\mathrm{C}$ ring are called isoflavones. Those in which the $\mathrm{B}$ ring is linked in position 4 are called neo flavonoids, while those in which the B ring is linked in position 2 can be further subdivided into several subgroups on the basis of the structural features of the $\mathrm{C}$ ring. These subgroups are: flavones, flavonols, flavanones, flavanonols, flavanols or catechins, anthocyanins and chalcones as shown in figure (2).

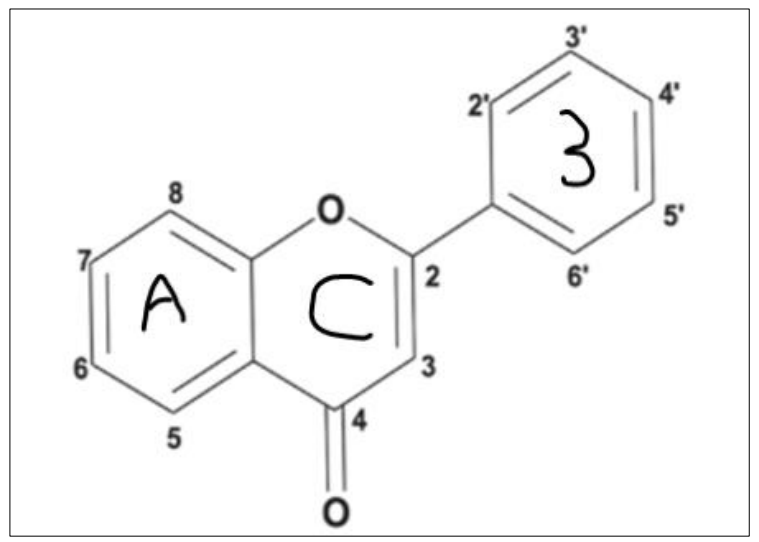

Figure 1 Basic skeleton or structure of flavonoids

Flavonoids are biosynthesized from a phenyl propane-derived unit (C6- C3), the later source or origin is from shikimate (from the amino acid phenylalanine) and an additional six carbons unit which is obtained from poly ketide biosynthetic pathway. This poly ketide unit is synthesized from 3 units of malonyl-CoA, that are combined with the phenyl propane derived unit (which is found as a CoA thioester) to generate the triketide molecule as a starter so that flavonoids are biosynthesized by mixed pathways, including of fragments derived or obtained from both polyketide and shikimic acid pathways [39].

All previous compounds are illustrated as the major constituents in the Equisetum arvense plant. Major constituent in ethanolic extract of the plant is (quercetin3-0-glucoside) which is also known as (isoquercitrin), other glycosides are available is considerable amounts such as kaempferol 3-0-glycoside and apigenin 5-0-glucoside [17]. Quercetin is available in high concentrations, about $50 \%$ of all total flavonoids in plant, but as the weather changes into summer and becomes hotter, the quercetin amounts decrease rapidly [40]. The importance of the flavonoids is their health benefit by acting as a free radicals scavenger converting them into much more 'stable radical' which in turn would undergo reaction with another 'flavonoid radical' to yield two non-radicals [41]. 


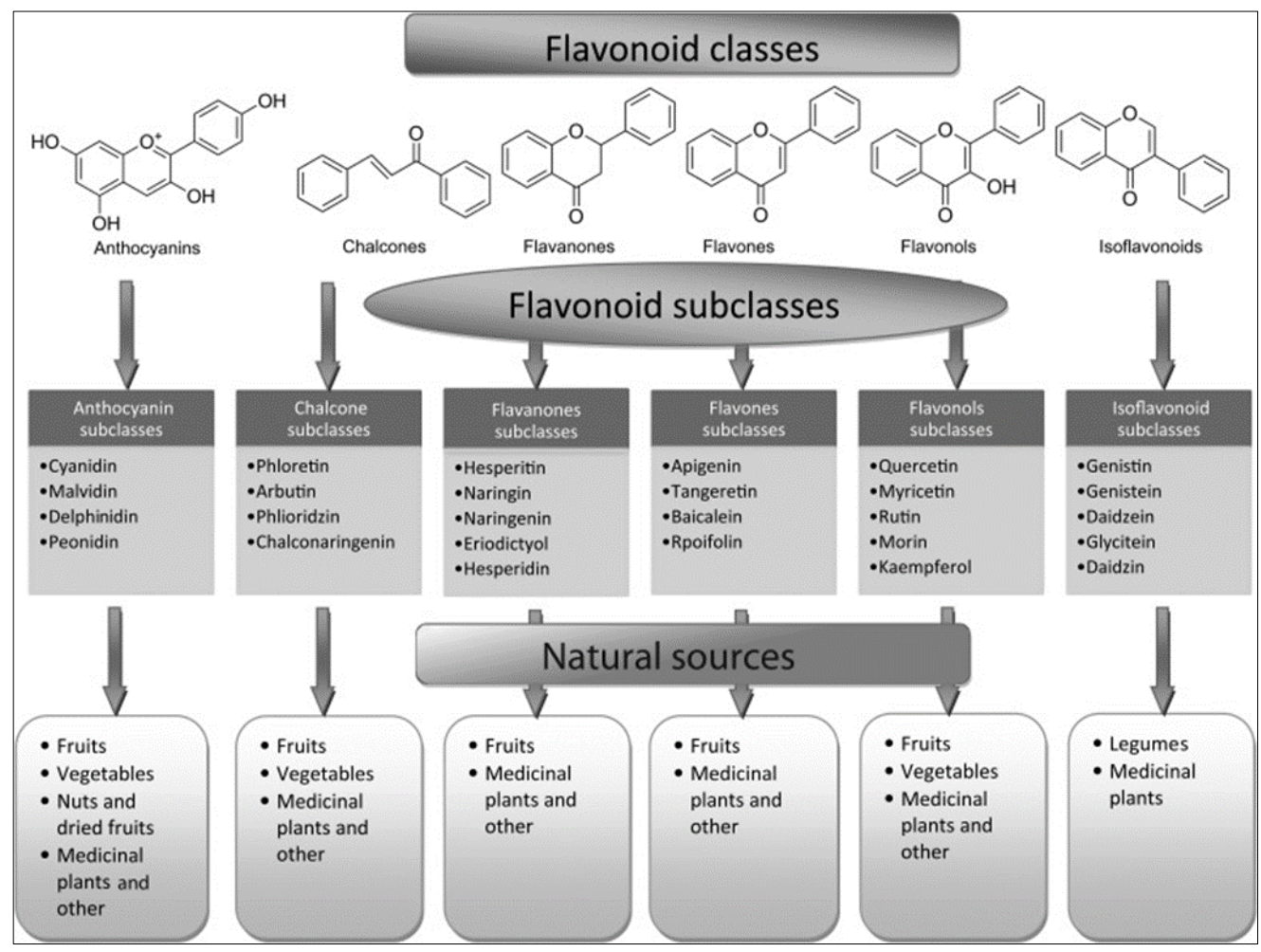

Figure 2 Flavonoid classes, subclasses and natural sources

\subsection{Caffeic acid ester (about one percent)}

These compounds are including chlorogenic acid, and dicoffeoyl-mesotartaric acid, their role in plant is thought to be a protective agent against pests or microbes, while their pharmacological actions are antibacterial, and antiviral [42].

\subsection{Silicic acid (about five percent)}

It has role in regulating metabolism of different classes of secondary metabolites especially phenolic compounds, new studies shows that silicon-treated plants produces significantly higher amounts of flavonoids than their intact correspondent (43). Some European clinical studies reported that bone fractures heal significantly faster when Equisetum arvense is used because of its high content of silica, also for the same reason it shows to decrease the incidence of osteoporosis more greatly when Equisetum arvense is routinely used [10].

\subsection{Alkaloids}

The term Alkaloid is derived from the word alkaline; it previously was referred to any Nitrogen-containing compound. They are biosynthesized by many beings, including bacteria, fungi, plants, and even animals. Many of them have a pharmacological action and indicated to many therapeutic fields, such as caffeine, cocaine, nicotine, ephedrine and many others [44]. It is difficult to find a specific definition for the term 'alkaloid' (alkalilike) due to that there is no clear-cut border between alkaloid itself and other naturally occurring complex amines, the following is the most accepted classification for alkaloids:

- Typical alkaloids are defined as that extracted from plants, alkaline, and has at least a nitrogen atom (usually in a heterocyclic ring) in addition to that, usually they have a marked pharmacological use either on human or on animals.

- Proto-alkaloid: sometimes called 'amino-alkaloid' is a term occaisionally applied to refer to compounds such as colchicine and ephedrine in which one or more of the features mentioned above of the typical alkaloids is absent.

- Other alkaloids: they aren't fit with conventional or general alkaloids definitions, they are chemically synthesized, not extracted from any natural source, at the same time they have a strong correlation to the naturally occurring alkaloids (such as the anticholinergic agent homatropine) [45]. In Pharmacognosy practice, these compounds are found in plants and gives positive results with the standard qualitative tests specified for alkaloids, and frequently in plant researched these tests alone are used to identify a plant as 'alkaloid- 
containing [46]. Alkaloids are reported to be present in E. arvense [48], are mainly from the Pyridine alkaloid class, nicotine and palustrine are the main alkaloids reported to be present in Equisetum arvense [47].

\subsection{Triterpinoids}

Naturally occurring secondary metabolites, have a crucial role in regulation of plant interaction with its media or environment, they may have a defense role to the plant, to prevent animals from feeding on the plant, or may have an attractant role in the plant, and many of them have a pharmacological activity for animal and humans [49]. Among phytochemicals that are reported to be found in Equisetum arvense that belong to this class, (Isobauerenol, taraxerol, germanicol, ursolic acid, oleanolic acid, betulinic acid), Betulinic acid is pentacyclic compound with a well-known anticancer activity [10].

\section{Conclusion}

The plant is reported to contain a number flavonoids, alkaloids, phenolic proteins, triterpenoids, saponins, phytosterols; the present review is an attempt to generate interest among the masses regarding its immense potential in preventing and treating several disorders.

\section{Compliance with ethical standards}

\section{Acknowledgments}

We would like to thank Al-Nahrain University for their support during this work.

\section{Disclosure of conflict of interest}

All authors of the manuscript have no conflict of interests to declare.

\section{References}

[1] Kshetrimayum B. Medicinal plants and its therapeutic uses. 2017.

[2] Ghazanfar SA. Arabian medicinal plants. CRC press, Inc. 1994.

[3] Chakravarty HL. Plant wealth of Iraq. Botany Directorate, Ministry of Agriculture and Agrarian Reform, Baghdad, Iraq. 1976; 1.

[4] Weber R. Equisetites aequecaliginosus sp. nov., ein Riesenschachtelhalm aus der spättriassischen Formation Santa Clara, Sonora, Mexico. Revue de paléobiologie. 2005; 24(1): 331-364.

[5] Hauke RL. A taxonomical monograph of the genus Equisetum subgenus Hippochaete. Beheifte zur Nova hedwigia. 1963; 8: 1-123.

[6] NIKLAS KJ. The evolutionary biology of plants. University of Chicago Press. Annals of botany. 1997; 79(3): 265272

[7] Rutishauser R. Polymerous leaf whorls in vascular plants: developmental morphology and fuzziness of organ identities. International Journal of Plant Sciences. 1999; 160(S6): S81-S103.

[8] Barkley TM, Brouillet L, Jeude H, Strother JL, Gandhi K, Kiger RW, Zarucchi JL. Flora of North America north of Mexico. 2006; 20.

[9] Hauke RL. Equisetaceae. In: Flora of North America Editorial Committee (Editors), Flora of North America: North of Mexico Volume 2: Pteridophytes and Gymnosperms. Oxford University Press, New York, NY. 1993; 76-84.

[10] Sandhu NS, Kaur SARABJIT, Chopra DIVNEET. Equisetum arvense: pharmacology and phytochemistry-a review. Asian journal of pharmaceutical and clinical research. 2010; 3(3): 146-150.

[11] Husby C. Biology and functional ecology of Equisetum with emphasis on the giant horsetails. The Botanical Review. 2013; 79(2): 147-177.

[12] Hultén E, Fries M. Atlas of North European vascular plants north of the Tropic of Cancer. Koeltz Scientific. 1986.

[13] Holm L, Pancho JV, Herberger JP, Plucknett DL. A geographical atlas of world weeds. John Wiley and Sons. 1991. 
[14] Townsend CC, Guest E. 1985 Flora of Iraq. Baghdad: Ministry of Agriculture and Agrarian Reform. 1966; 2-8.

[15] Maulood BK, AL-Khasraji TO, Ismail AM. A study on pteridoflora of Kurdistan of Iraq: A morphological study and distribution of Equisetum L. (Horse tail) in Iraqi Kurdistan. Int. J of Emerging Technologies in Computinonal and Applied Science. 2016; 18(1): 78-84.

[16] Dos Santos Jr JG, Blanco MM, Do Monte FHM, Russi M, Lanziotti VMNB, Leal LKAM, Cunha GM. Sedative and anticonvulsant effects of hydroalcoholic extract of Equisetum arvense. Fitoterapia. 2005; 76(6): 508-513.

[17] Mimica-Dukic N, Simin N, Cvejic J, Jovin E, Orcic D, Bozin B. Phenolic compounds in field horsetail (Equisetum arvense L.) as natural antioxidants. Molecules. 2008; 13(7): 1455-1464.

[18] Sinha SN. In vitro antibacterial activity of ethanolic extract of Equisetum arvense L. Indian Journal of Pharmaceutical and Biological Research. 2012; 3(1): 19-21.

[19] Briskin DP. Medicinal plants and phytomedicines. Linking plant biochemistry and physiology to human health. Plant physiology. 2000; 124(2): 507-514.

[20] Milovanović V, Radulović N, Todorović Z, Stanković M, Stojanović G. Antioxidant, antimicrobial and genotoxicity screening of hydro-alcoholic extracts of five Serbian Equisetum species. Plant Foods for Human Nutrition. 2007; 62(3): 113-119.

[21] Štajner D, Popović BM, Čanadanović-Brunet J, Anačkov G. Exploring Equisetum arvense L., Equisetum ramosissimum L. and Equisetum telmateia L. as sources of natural antioxidants. Phytotherapy Research: An International Journal Devoted to Pharmacological and Toxicological Evaluation of Natural Product Derivatives. 2009; 23(4): 546-550.

[22] Carnet A, Petitjean-Freytet C, Muller D, Lamaison JL. Content of major constituents of horsetails, Equisetum arvense L. Plants Med. Phytother. 1991; 25(1): 32-38.

[23] Holzhüter G, Narayanan K, Gerber T. Structure of silica in Equisetum arvense. Analytical and Bioanalytical Chemistry. 2003; 376(4): 512-517.

[24] Sola-Rabada A, Rinck J, Belton DJ, Powell AK, Perry CC. Isolation of a wide range of minerals from a thermally treated plant: Equisetum arvense, a Mare's tale. JBIC Journal of Biological Inorganic Chemistry. 2016; 21(1): 101112.

[25] Četojević-Simin DD, Čanadanović-Brunet JM, Bogdanović GM, Djilas SM, Ćetković GS, Tumbas VT, Stojiljković BT. Antioxidative and antiproliferative activities of different horsetail (Equisetum arvense L.) extracts. Journal of medicinal food. 2010; 13(2): 452-459.

[26] Čanadanović-Brunet JM, Ćetković GS, Djilas SM, Tumbas VT, Savatović SS, Mandić AI, Cvetković DD. Radical scavenging and antimicrobial activity of horsetail (Equisetum arvense L.) extracts. International journal of food science \& technology. 2009; 44(2): 269-278.

[27] Oh H, Kim DH, Cho JH, Kim YC. Hepatoprotective and free radical scavenging activities of phenolic petrosins and flavonoids isolated from Equisetum arvense. Journal of Ethnopharmacology. 2004; 95(2-3): 421-424.

[28] Briskin DP. Medicinal plants and phytomedicines. Linking plant biochemistry and physiology to human health. Plant physiology. 2000; 124(2): 507-514.

[29] Carneiro DM, Freire RC, Honório TCDD, Zoghaib I, Cardoso FFDS, Tresvenzol LMF, Cunha LCD. Randomized, double-blind clinical trial to assess the acute diuretic effect of Equisetum arvense (field horsetail) in healthy volunteers. Evidence-Based Complementary and Alternative Medicine. 2014.

[30] Radulović N, Stojanović G, Palić R. Composition and antimicrobial activity of Equisetum arvense L. essential oil. Phytotherapy Research: An International Journal Devoted to Pharmacological and Toxicological Evaluation of Natural Product Derivatives. 2006; 20(1): 85-88.

[31] Nagai T, Myoda T, Nagashima T. Antioxidative activities of water extract and ethanol extract from field horsetail (tsukushi) Equisetum arvense L. Food chemistry. 2005; 91(3): 389-394.

[32] Do Monte FHM, dos Santos Jr JG, Russi M, Lanziotti VMNB, Leal LKAM, de Andrade Cunha GM. Antinociceptive and anti-inflammatory properties of the hydroalcoholic extract of stems from Equisetum arvense L. in mice. Pharmacological research. 2004; 49(3): 239-243.

[33] Oh H, Kim D-H, Cho J-H, Kim Y-C. Hepatoprotective and free radical scavenging activities of phenolic petrosins and flavonoids isolated from Equisetum arvense L. Journal of Ethnopharmacology. 2005; 95: 421-424. 
[34] Veit M, Beckert C, Höhne C, Bauer K, Geiger H. Interspecific and intraspecific variation of phenolics in the genus Equisetum subgenus Equisetum. Phytochemistry. 1995; 38(4): 881-891.

[35] Beckert C, Horn C, Schnitzler J-P, Lehning A, Heller W, Veit M. Styrylpyrone biosynthesis in Equisetum arvense. Phytochemistry. 1997; 44: 275-283.

[36] Gierlinger N, Sapei L, Paris O. Insights into the chemical composition of Equisetum hyemale by high resolution Raman imaging. Planta. 2008; 227(5): 969-980.

[37] Law C, Exley C. New insight into silica deposition in horsetail (Equisetum arvense). BMC plant biology. $2011 ; 11(1): 1-9$.

[38] De Souza Farias SA, da Costa KS, Martins JB. Analysis of Conformational, Structural, Magnetic, and Electronic Properties Related to Antioxidant Activity: Revisiting Flavan, Anthocyanidin, Flavanone, Flavonol, Isoflavone, Flavone, and Flavan-3-ol. ACS omega. 2021; 6(13): 8908-8918.

[39] Heinrich M, Williamson EM, Gibbons S, Barnes J, Prieto-Garcia J. Fundamentals of pharmacognosy and phytotherapy E-BOOK. Elsevier Health Sciences. 2017.

[40] Kane CW. Herbal Medicine of the American Southwest: A Guide to the Medicinal and Edible Plants of the Southwestern United States. Lincoln Town Press. 2006.

[41] Kar A. Advanced practical medicinal chemistry. New Age International. 2007.

[42] Hoshfeld M, Veit M, Strack D. Hydroxycinnamoyltransferases involved in the accumulation of caffeic acid esters in gametophytes and sporophytes of Equisetum arvense. Plant physiology. 1996; 111(4): 1153-1159.

[43] Li WB, Shi XH, Wang H, Zhang FS. Effects of silicon on rice leaves resistance to ultraviolet-B. ACTA BOTANICA SINICA-ENGLISH EDITION. 2004; 46(6): 691-697.

[44] Kakhia TI. Alkaloids and alkaloids plants. Adana University-Industry Joint Research Center. 2012.

[45] Evans WC. Trease and evans' pharmacognosy E-book. Elsevier Health Sciences. 2009.

[46] Aniszewski T. Alkaloids-Secrets of Life: Aklaloid Chemistry, Biological Significance, Applications and Ecological Role. Elsevier. 2007.

[47] Chakravarty HL. Plant wealth of Iraq. Ministry of agriculture and agrarian reform. Iraq. Baghdad. $1976 ; 505$.

[48] Albadri, H. M. B. (2016). Phytochemical Investigation of L. arvense Equisetum Horsetail (Doctoral dissertation, Ministry of Higher Education).

[49] James JT, Dubery IA. Pentacyclic triterpenoids from the medicinal herb, Centella asiatica (L.) Urban. Molecules. 2009; 14(10): 3922-3941. 